\title{
The College Wealth Divide Continues to Grow
}

\author{
Alina K. Bartscher, Ph.D. Candidate, University of Bonn \\ Moritz Kuhn, Professor, University of Bonn \\ Moritz Schularick, Professor, University of Bonn
}

ince the 1980s, wage differences between individuals with a college degree and individuals without a college degree have increased in a remarkable manner (see, e.g., Levy and Murnane, 1992; Katz and Autor, 1999; and Goldin and Katz, 2007). Among the explanations for this trend are skill-biased technical change, socio-demographic factors, and institutional features (Card and Lemieux, 2001, and Fortin, 2006). Recently, attention has shifted toward other trends for households whose head holds a college degree (college households) and households whose head does not hold a college degree (noncollege households), in particular the relationship between college education and wealth inequality (Emmons, Kent, and Ricketts, 2018, and Pfeffer, 2018).

In our article "The College Wealth Divide: Education and Inequality in America, 1956-2016" (Bartscher, Kuhn, and Schularick, 2020), we focus on wealth differences between college and noncollege households-the college wealth premium. Using newly available microdata representative of the U.S. population, we document that the college wealth premium has increased threefold since the 1970s. We build on the work of Kuhn, Schularick, and Steins (forthcoming), who have combined and harmonized data

Figure 1

Wealth and Income Levels, 1956-2016

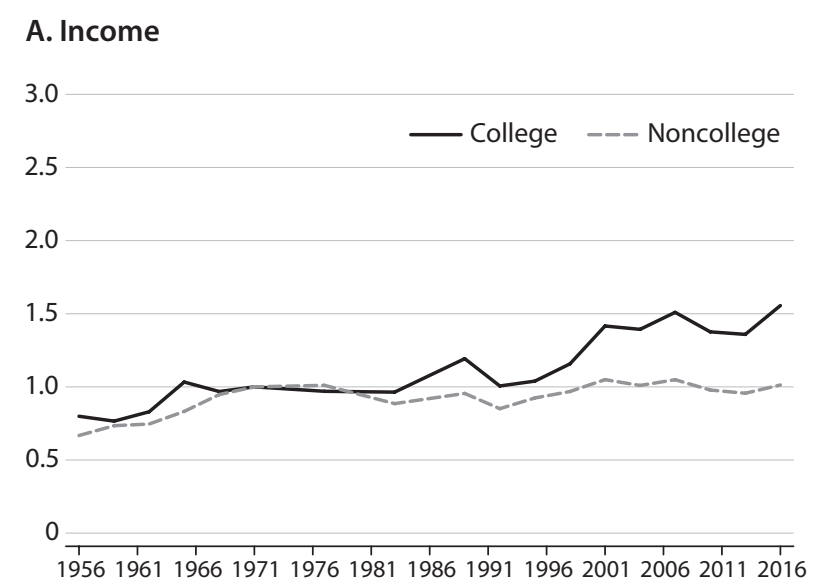

from the post-1983 Survey of Consumer Finances (SCF) with its predecessor surveys dating back to the postwar era. The combined "SCF+" data close a gap in the availability of high-quality microdata over a long horizon.

\section{The college wealth premium has} increased threefold since the 1970s.

Our analysis corroborates the strong increase in the difference between college and noncollege income since the early 1980s. The average income of college households has increased by about 50 percent in real terms (Panel A of Figure 1). However, the increase of the college income premium is dwarfed by that of the college wealth premium (Panel B of Figure 1). The wealth of college households tripled between 1971 and 2016, while the wealth of noncollege households barely grew at all. We document that a substantial part of this widening wealth gap is driven by strong wealth gains within the top 10 percent of the wealth distribution.

\section{B. Wealth}

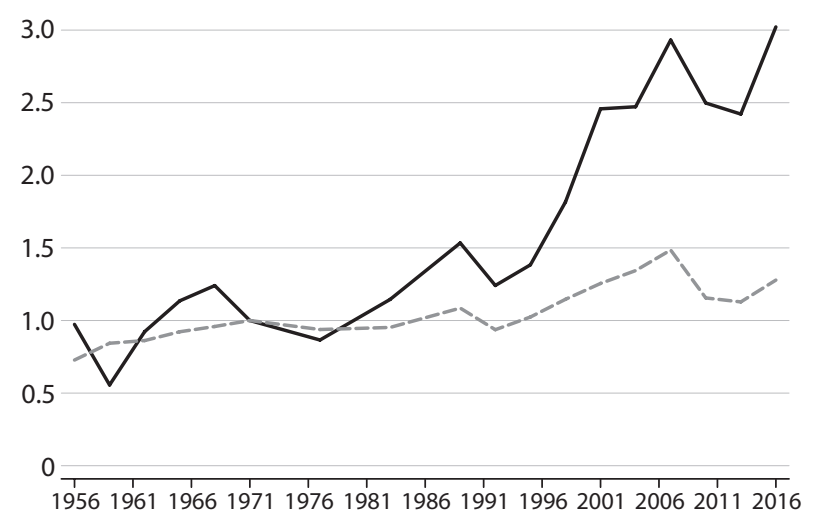

NOTE: Panel A (Panel B) shows the average income (average wealth) of college and noncollege households. 


\section{Figure 2}

Shares Within Education Group, 1956-2016

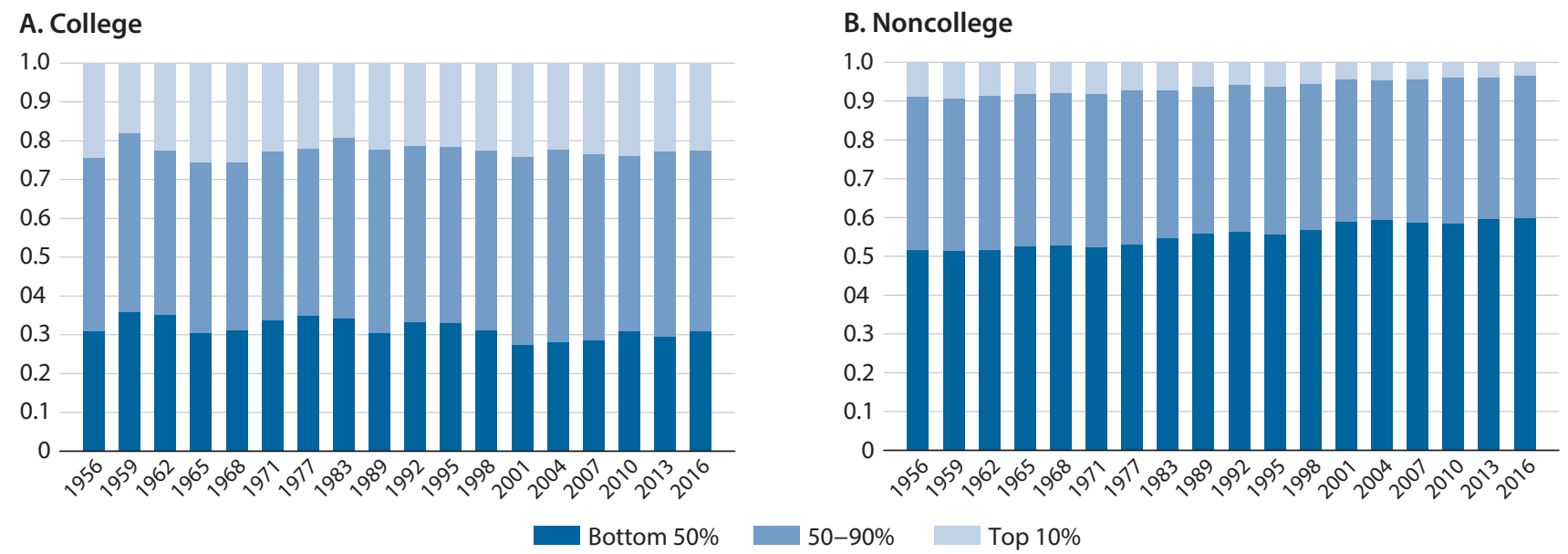

NOTE: The figure shows the share of households belonging to the bottom 50 percent, $50-90$ percent, and top 10 percent of the aggregate wealth distribution for college (Panel A) and noncollege households (Panel B).

Figure 3

Portfolio Shares of College and Noncollege Households, 1956-2016

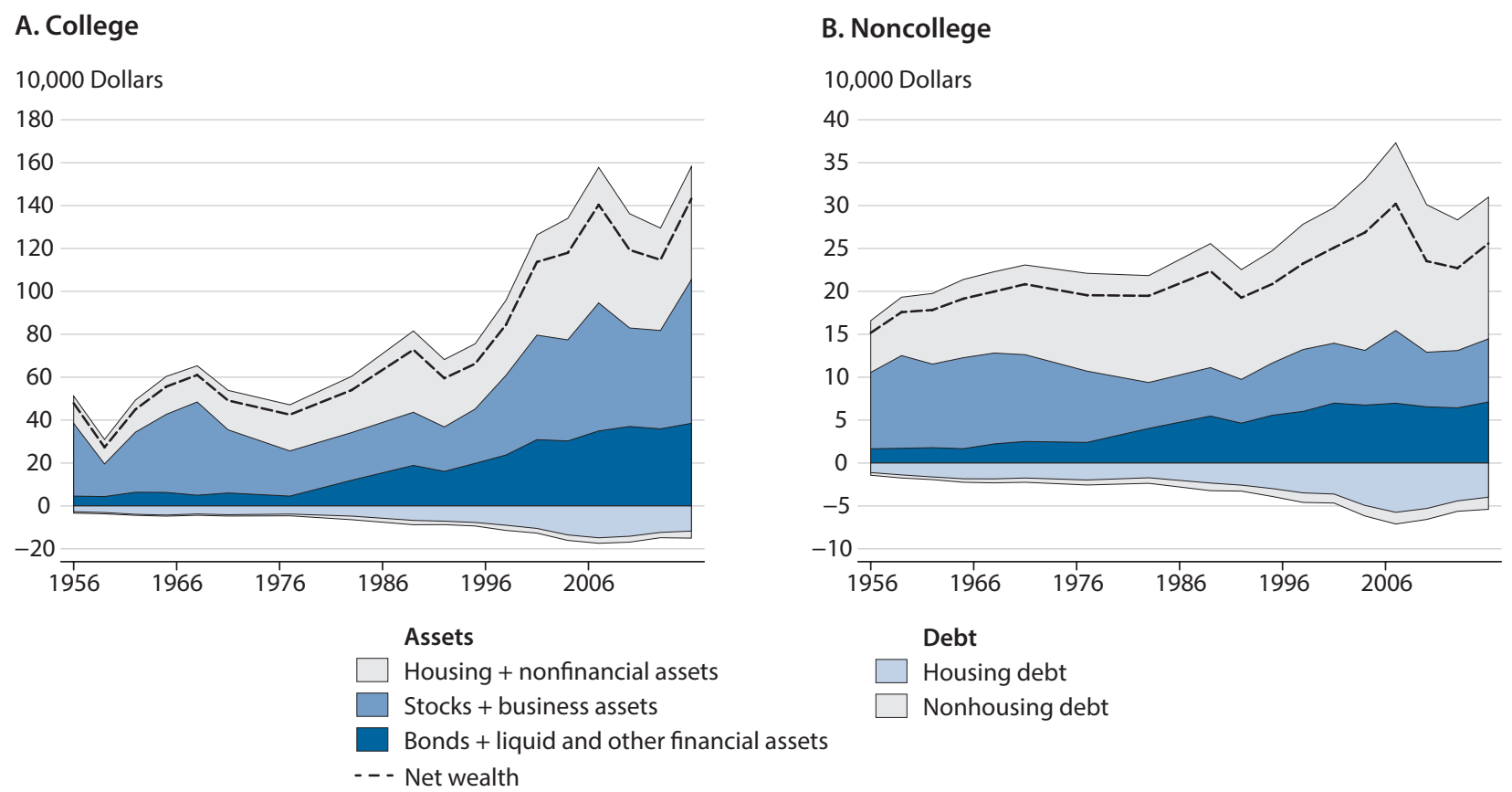

NOTE: Panel A (Panel B) shows the portfolio composition of college (noncollege) households. Housing includes nonresidential real estate. Stocks include mutual fund holdings and other managed assets.

Looking at who makes it to the top 10 percent of the wealth distribution, we find that the share of noncollege households in the group has declined over time (Figure 2). By contrast, the share of college households making it to this group has remained remarkably stable over time. Our results therefore suggest that obtaining a college degree does not increase the probability of making it to the top 10 percent. A college degree seems to help households to keep pace, but not to reach the top. We additionally document that households with two college-educated spouses have enjoyed particularly large gains in wealth. Yet this trend is not driven by assortative matching but by the overall 
growth in college education. Consistent with the findings of Eika, Mogstad, and Zafar (forthcoming), assortative mating has even decreased among college graduates over time.

An important question raised by our findings is why the ratio of college to noncollege wealth has grown so much more than the income gap. The workhorse economic models of wealth accumulation imply a tight comovement of income and wealth differences, as savings out of income is the sole determinant of wealth. We demonstrate that college and noncollege households exhibit systematic differences not only in the sizes of their asset holdings but also in the compositions of their portfolios. College households own a higher share of stocks and mutual funds (Figure 3). Consequently, college and noncollege households are differentially exposed to asset price changes. College households reap disproportionately high capital gains during stock market booms. Importantly, such capital gains are unrelated to income, as total household income in the SCF+ excludes capital gains. This finding is consistent with the decoupling of the evolution of the college income and wealth premiums since the 1980s (see also Kuhn, Schularick, and Steins, forthcoming). Using explorative regression analysis, we also find some indication that business ownership matters for the increase of the college wealth premium, especially since the late 1990s. The fact that the college wealth advantage is associated with equity holdings and business ownership may be related to higher levels of financial literacy and entrepreneurial skills among college households. These features can affect wealth via portfolio composition and differential returns (cf. Lusardi, Michaud, and Mitchell, 2017; Von Gaudecker 2015; and Fagereng et al., 2018).

While we document a sharply rising college wealth premium in recent decades, it is important to note that causality can run in both directions. College graduates may hold more wealth due to their higher educational attainment, but there is also evidence that it is easier to obtain college degrees when coming from a wealthy family (see, e.g., Pfeffer, 2018, and Pfeffer and Killewald, 2018). We hope that our findings will spur further research to disentangle different hypotheses for the rising college wealth premium and establish causal relationships.

\section{References}

Bartscher, Alina K.; Kuhn, Moritz and Moritz Schularick. "The College Wealth Divide: Education and Inequality in America, 1956-2016." Federal Reserve Bank of St. Louis Review, First Quarter 2020, 102(1), pp. 19-49; https://doi.org/10.20955/r.102.19-49.

Card, D. and Lemieux, T. "Can Falling Supply Explain the Rising Return to College for Younger Men? A Cohort-Based Analysis." Quarterly Journal of Economics, 2001, 116, pp. 705-46.

Eika, L.; Mogstad, M., and Zafar, B. “Educational Assortative Mating and Household Income Inequality." Journal of Political Economy (forthcoming)

Emmons, W.R.; Kent, A.H. and Ricketts, L.R. "The Financial Returns from College across Generations: Large but Unequal." Federal Reserve Bank of St. Louis The Demographics of Wealth 2018 Series, 2018, Essay No. 1;

https://www.stlouisfed.org/household-financial-stability/the-demographics-of-wealth/the-financial-returns-from-college-across-generations.

Fagereng, A., Guiso, L.; Malacrino, D. and Pistaferri L. "Heterogeneity and Persistence in Returns to Wealth." Working paper, 2018.

Fortin, N.M. "Higher-Education Policies and the College Wage Premium: Cross-State Evidence from the 1990s." American Economic Review, 2006, 96, pp. 959-87.

Goldin, C. and Katz, L.F. "Long-Run Changes in the Wage Structure: Narrowing, Widening, Polarizing." Brookings Papers on Economic Activity, 2007, 38, pp. 135-68.

Katz, L.F. and Autor, D.H. "Changes in the Wage Structure and Earnings Inequality" in O. Ashenfelter and D. Card, eds., Handbook of Labor Economics. Vol. 3, Chap. 26. Elsevier, 1999, pp. 1463-555.

Kuhn, M.; Schularick, M. and Steins, U.I. "Income and Wealth Inequality in America." Journal of Political Economy (forthcoming).

Levy, F. and Murnane, R.J. "U.S. Earnings Levels and Earnings Inequality: A Review of Recent Trends and Proposed Explanations." Journal of Economic Literature, 1992, 30, pp. 1333-81.

Lusardi, A.; Michaud, P.-C. and Mitchell, O.S. "Optimal Financial Knowledge and Wealth Inequality." Journal of Political Economy, 2017, 125, pp. 431-77.

Pfeffer, F.T. "Growing Wealth Gaps in Education." Demography, 2018, 55, pp. 1033-68.

Pfeffer, F.T. and Killewald, A. "Generations of Advantage: Multigenerational Correlations in Family Wealth." Social Forces, 2018, 96, pp. 1411-42.

Von Gaudecker, H.-M. "How Does Household Portfolio Diversification Vary with Financial Literacy and Financial Advice?" Journal of Finance, 2015, 70, pp. 489-507. 